\title{
Polymerase chain reaction for the diagnosis of bovine genital campylobacteriosis ${ }^{1}$
}

\author{
Ana C.M. Groff ${ }^{2}$, Jackeline K. Kirinus², Mariana Sá e Silva², Gustavo \\ Machado $^{2}$, Mateus M. Costa ${ }^{3}$ and Agueda P.C. Vargas ${ }^{*}$
}

\begin{abstract}
Groff A.C.M., Kirinus J.K., Sá e Silva M., Machado G., Costa M.M. \& Vargas A.P.C. 2010. Polymerase chain reaction for the diagnosis of bovine genital campylobacteriosis. Pesquisa Veterinária Brasileira 30(12):1031-1035. Laboratório de Bacteriologia, Departamento de Medicina Veterinária Preventiva, Centro de Ciências Rurais, Universidade Federal de Santa Maria, Av. Roraima 1000, Santa Maria, RS 97105-900, Brazil. E-mail: agueda.vargas@gmail.com

Bovine genital campylobacteriosis is a common venereal disease of cattle; the prevalence of this disease can be underestimated mostly because of the nature of the etiological agent, the microaerobic Campylobacter fetus subspecies venerealis. The purpose of the current study was to evaluate the utilization of polymerase chain reaction (PCR) in the diagnosis of genital campylobacteriosis in samples obtained from bull prepuce aspirate, cow cervical mucus, and abomasum contents of aborted fetuses, collected into enrichment medium. Five different DNA extraction protocols were tested: thermal extraction, lysis with proteinase $\mathrm{K}$, lysis with guanidine isothiocyanate, lysis with DNAzol, and lysis with hexadecyltrimethylammonium bromide (CTAB). The specificity, sensitivity, and technical application of the PCR assay were also evaluated with clinical samples and compared to bacterial isolation by standard culture. DNA extraction by the CTAB protocol provided better results in PCR, and it was able to detect 63 colony-forming units per $\mathrm{ml}$ of $C$. fetus. Out of 277 clinical samples tested, 68 (24\%) were positive for Campylobacter fetus using PCR, while only $8(2.8 \%)$ of the samples were positive by bacterial isolation in solid medium, proving the superiority of the PCR technique when compared to the standard isolation method, and providing evidence for its usefulness as a better screening test in cattle for the diagnosis of bovine genital campylobacteriosis.
\end{abstract}

INDEX TERMS: Bovine genital campylobacteriosis, Campylobacter fetus, diagnosis, abortion.

RESUMO.- [Reação em cadeia da polimerase para o diagnóstico de campilobacteriose genital bovina.] Campilobacteriose genital bovina é uma doença venérea comum em bovinos. A prevalência desta doença pode ser subestimada na maioria das vezes pela natureza microaeróbica do agente etiológico, Campylobacter fetus subspecies venerealis. O propósito do presente estudo foi avaliar a utilização

\footnotetext{
${ }^{1}$ Received on January 12, 2010.

Accepted for publication on August 5, 2010.

2 Laboratório de Bacteriologia, Departamento de Medicina Veterinária Preventiva, Centro de Ciências Rurais, Universidade Federal de Santa Maria, Av. Roraima 1000, Santa Maria, RS 97105-900, Brazil. ${ }^{*}$ Corresponding author: agueda.vargas@gmail.com

${ }^{3}$ Laboratório de Microbiologia e Imunologia Animal, Campus de Ciências Agrárias, Universidade Federal do Vale do São Francisco, Rodovia BR 407 Km12, Lote 543, Petrolina, PE 56300-000, Brazil.
}

da reação de polimerase em cadeia (PCR) no diagnóstico de campilobacteriose genital em amostras obtidas de aspirado prepucial de touros, muco cervical de vacas e conteúdo abomasal de fetos abortados, coletados em meio enriquecido. Cinco protocolos diferentes de extração de DNA foram testados: termo extração, lise com proteinase $\mathrm{K}$, lise com guanidine isothiocyanate, lise com DNAzol e lise com hexadeciltrimetilamônio brometo (CTAB). A especificidade, sensibilidade e a aplicação da técnica da PCR foram também avaliadas com amostras clínicas e comparadas com bactérias isoladas por cultura padrão. DNA extraído pelo protocolo de CTAB demonstrou os melhores resultados na PCR, e foi capaz de detectar 63 unidades formadoras de colônias de C. fetus por $\mathrm{ml}$ de meio. Das 277 amostras clínicas testadas, 68 (24\%) foram positivas para Campylobacter fetus pela PCR, enquanto $8(2,8 \%)$ das 
amostras foram positivas por isolamento bacteriológico, provando a superioridade da técnica de PCR quando comparada com métodos padrão de isolamento, e fornecendo evidências de sua utilização como um teste de melhor projeção para diagnóstico em campilobacteriose genital bovina.

TERMOS DE INDEXAÇÃO: Campilobacteriose genital bovina, Campylobacter fetus, diagnóstico, aborto.

\section{INTRODUCTION}

Bovine genital campylobacteriosis (BGC) is a venereal disease and one of the most important causes of infection related to infertility in cattle (Casadémont et al. 2000). The etiological agent of BGC is a Gram-negative, spiral-shaped bacterium Campylobacter fetus, which infects biungulates and humans (Eaglesome \& Garcia 1992). Campylobacter fetus species is divided into 2 genotypic subspecies, each with distinct epidemiological features (Muller et al. 2003). Campylobacter fetus subspecies fetus can be found in the intestinal tract of bovine and ovine, and can sporadically cause abortion and infertility, while in humans it is associated with other systemic infections (On \& Harrington 2001). In contrast, $C$. fetus subsp. venerealis is better adapted to the bovine reproductive tract, does not survive in bovine or ovine intestinal tract (Wagenaar et al. 2001), and is not an important human pathogen (Catena et al. 2003).

The isolation and identification of the organism by culture is accepted as "gold standard" method to confirm the diagnosis of $C$. fetus infection; however, the reduced viability of the agent in clinical samples could be affecting the obtained results (Brooks et al. 2004). Other methods such as direct fluorescent antibody test, cervical mucus agglutination, and enzyme-linked immunosorbent assay (ELISA) are also used for diagnosis; however, they present limitations in sensitivity and specificity (Hum et al. 1994, Brooks et al. 2004, McFadden et al. 2005).

The PCR assay has also been used for $C$. fetus identification (Bastyns et al. 1994, Blom et al. 1995, Oyarzabal et al. 1997) and its subspecies (Hum et al. 1997, Muller et al. 2003, On \& Harrington 2001, Wagenaar et al. 2001). The aim of the current study was to evaluate the utilization of PCR for the screening of bovine venereal campylobacteriosis directly from clinical samples and compare the technique with the traditional isolation methods.

\section{MATERIALS AND METHODS}

\section{Bacterial strains}

The control strains used in the experiments were Campylobacter fetus subsp. fetus (ATCC 27374), C. fetus subsp. venerealis (ATCC 19438), Escherichia coli (ATCC 25922), Pseudomonas spp. (ATCC 27853), Proteus spp. (ATCC 29906), Bacillus spp. (Routine Labac/SB 177/94), C. sputorum subsp. bubulus (ATCC 33562), and C. sputorum subsp. sputorum (ATCC 35980). The Campylobacter spp. strains were cultivated in 10\% sheep blood agar plates, incubated for $48 \mathrm{hr}$ at $37^{\circ} \mathrm{C}$ in microaerobic conditions ( $5 \%$ oxygen, $8 \%$ carbon dioxide, $87 \%$ nitrogen); the remaining strains were incubated in aerobic conditions for $48 \mathrm{hr}$ at $37^{\circ} \mathrm{C}$ in blood agar.

\section{DNA extraction of Campylobacter fetus and sensitivity}

To evaluate DNA extraction methods, the reference strain of $C$. fetus subsp. venerealis was resuspended in ultrapure water adjusted to 0.5 in the McFarland scale, logarithmically diluted (from $10^{0}$ to $10^{-7}$ ), and cultivated $(10 \mathrm{ml}$ ) for bacterial counting. From these dilutions, $100 \mathrm{ml}$ was added to $500 \mathrm{ml}$ of ultrapure water and submitted to 5 different DNA extraction protocols: 1) thermal extraction; 2) proteinase K (USB Corp., Cleveland, OH) lysis (Rapley \& Walker 1998); 3) guanidine isothiocyanate lysis (Pitcher et al. 1989); 4) lysis with DNAzol reagent (GIBCO/Invitrogen Corp.); and 5) lysis with CTAB (FeF Chemicals $A / S$ ) (hexadecyltrimethylammonium bromide) predigested with $5 \mathrm{ml}$ of proteinase K (USB Corp.), $(20 \mathrm{mg} / \mathrm{ml})$ for $60 \mathrm{~min}$ at $37^{\circ} \mathrm{C}$ (Sambrook \& Russel 2001).

\section{PCR technique}

The amplification conditions were as previously described (Lander 1990, Hum et al. 1997) and modified (Vargas et al. 2003) The species-specific primers used were MG3F (5'GGTAGCCGCAGCTGCTAAGAT-3') and MG4R (5'-TAG CTA CAA TAA CGA CAA CT-3'), with amplicon of $750 \mathrm{bp}$ and also for positive samples a subspecies venerealis specific PCR was used, being VenSF (5'-CTT AGC AGT TTG CGA TAT TGC CAT T-3') and VenSR (5'-GCT TTT GAG ATA ACA ATA AGA GCT T3') with amplicon for $142 \mathrm{bp}$ (Hum et al. 1997). DNA template $(5 \mathrm{ml})$ was mixed with $45 \mathrm{ml}$ of PCR mix: $200 \mathrm{mmol}$ of each deoxyribonucleotide triphosphate (dNTP), 10x PCR buffer containing $10 \mathrm{mmol}$ Tris- $\mathrm{HCl}(\mathrm{pH} 8.4), 50 \mathrm{mmol} \mathrm{KCl}, 2.5 \mathrm{mmol}$ $\mathrm{MgCl}_{2}, 5 \mathrm{U}$ of Taq DNA polymerase (Ludwig Biotechnology Ltd), and $30 \mathrm{pmol}$ of primers. The mixture was submitted to an initial denaturation at $95^{\circ} \mathrm{C}$ for $3 \mathrm{~min}$ and cycled 30 times as follows: $95^{\circ} \mathrm{C}$ for $20 \mathrm{sec}, 52^{\circ} \mathrm{C}$ for $20 \mathrm{sec}$, and $72^{\circ} \mathrm{C}$ for $2 \mathrm{~min}$. The PCR fragments obtained were separated in $1.5 \%$ agarose gel, stained with ethidium bromide (Invitrogen Corp., Carlsbad, $\mathrm{CA})$, and observed under ultraviolet light.

\section{Specificity and sensitivity evaluation}

DNA samples were submitted to PCR employed related control bacteria as described above (bacterial strains) for specificity analysis. The identity of amplified products was confirmed by southern blot (Sambrook \& Russel 2001) The $C$. fetus subsp. venerealis strain was logarithmically diluted $\left(10^{-1}\right.$ to $10^{-7}$ ). DNA was extracted by CTAB protocol followed by PCR. The extracted DNA samples were mixed with transport enriched medium (TEM) (Lander 1990) and added to C. fetus-negative preputial mucus, cervical mucus, and fetus abomasums.

\section{Clinical samples}

A total of 545 bovine clinical samples were collected in 35 different cities in the Rio Grande do Sul State, Brazil from 71 farms with a history of infertility. Cervical mucus of cows (94), preputial mucus of bulls (447), and aborted fetus abomasum contents (4) were collected during the years 2002 to 2004 . The aspirated content (approx. $1 \mathrm{ml}$ ), was mixed with $3 \mathrm{ml}$ of TEM and stored at room temperature for 24 to $36 \mathrm{hr}$. The abomasal liquid from the fetuses was aseptically collected with a syringe and added to TEM.

\section{Isolation of Campylobacter fetus from field samples}

Culture and identification tests were realized (Lander 1990 , OIE 2004), after an incubation period of 3 days $\left(37^{\circ} \mathrm{C}\right)$, $30 \mathrm{ml}$ of the sample in TEM was placed into a $0.45-0.65 \mathrm{~mm}$ 
porosity filter over blood agar base no.2 plates with $10 \%$ sheep blood, and supplemented with antimicrobials (5 UI of polymyxin B sulfate (Laborclin Produtos para Laboratório Ltda), 10ml of trimethoprim (Laborclin Produtos para Laboratório Ltda), and $20 \mathrm{ml}$ of vancomycin $/ \mathrm{ml}$ of medium). After $30 \mathrm{~min}$, the filter was removed, the sample was spread with a loop and the plates were incubated at $37^{\circ} \mathrm{C}$ in microaerobic conditions.

\section{Application of PCR technique on clinical samples and statistical analysis}

The 545 samples collected were incubated in TEM at $37^{\circ} \mathrm{C}$ for 5 days, and then submitted to CTAB protocol for DNA extraction and PCR. An internal control for negative reactions was performed using one micro liters of a positive PCR product mixed with $10 \%$ of all negative PCR samples. The kappa $(\mathrm{k})$ test was used in 277 clinical samples (191 males, 85 females, and 1 abomasum sample) submitted to both techniques.

\section{RESULTS}

CTAB based method was determined as the best DNA extraction protocol during the current study because it allowed the detection of 63 CFU of Campylobacter fetus in PCR. Other methods only produce positive reactions when inoculated with higher CFU, being for thermal extraction $7.20 \times 10^{5}$; for proteinase $\mathrm{K} 2.46 \times 10^{4}$; for guanidine isothiocyanate $1.70 \times 10^{2}$; and for DNAzol $1.70 \times 10^{2}$. The identity of amplified products (750bp) was confirmed by Southern blot (Sambrook \& Russel 2001). The dilutions inoculated into TEM medium mixed with negative preputial mucus, cervical mucus, and abomasums content could be detected to the same limit (63 CFU). Only C. fetus DNA was amplified in specificity test and no other amplification was observed to control strains (E. coli, Pseudomonas spp., Proteus spp., Bacillus spp., Campylobacter sputorum subsp. bubulus, and $C$. sputorum subsp. sputorum).

The PCR on clinical samples yielded $12.5 \%(68 / 545)$ positive results for $C$. fetus, of the positive samples, $34 \%$ (32/94) were cervical mucus, 7.8\% (35/447) were preputial mucus, and $25 \%$ (1/4) from abomasum content. From the 71 farms, $40.8 \%$ (29/71) were positive for $C$. fetus. In all the farms, males and females were tested, but only females tested positive for $C$. fetus. To confirm the subspecies involved in C. fetus infectious some positives sample were submitted to a second PCR reaction with subspecies venerealis specific PCR. All tested samples presented positive results in PCR.

All negative samples submitted to an internal amplification control were PCR positive. The results of the comparison between PCR and isolation in culture are presented in (Table 1). From 277 clinical samples tested, $24 \%$ were positive for $C$. fetus using PCR, while only $2.8 \%$ of the samples were positive by bacterial isolation in culture. PCR was more efficient (8.5-fold) in detecting $C$. fetus when compared with isolation (Table 1). The kappa value found in the statistical analysis was 0.2 . From the farms analyzed by both techniques, $61.3 \%$ (19/31) were PCR positive, while only $6.4 \%(2 / 31)$ were positive by culture isolation.
Table 1. Comparison between polymerase chain reaction (PCR) technique and culture isolation for bovine genital campylobacteriosis diagnosis in cattle

\begin{tabular}{cccc}
\hline & \multicolumn{2}{c}{ Culture } & Total \\
\cline { 2 - 3 } & Positive & Negative & \\
\hline PCR & & & \\
Positive & 8 & 60 & 68 \\
Negative & 0 & 209 & 209 \\
Total & 8 & 269 & 277
\end{tabular}

\section{DISCUSSION}

The detergent CTAB produces a high-quality DNA and reduces potential inhibitors for the PCR reaction (Sambrook \& Russel 2001, Honoré-Bouakline et al. 2003) common in clinical samples such as cervical and preputial mucus. These characteristics explain the greater efficiency in the detection of Campylobacter fetus when the CTAB was applied. The primers used in the present did not amplify DNA of other bacteria that could be present in the genital tract of bovines, indicating the accuracy of PCR in obtaining a diagnosis of infection caused by $C$. fetus. The specificity of these primers was confirmed by previous studies (Hum et al. 1997, Muller et al. 2003, Vargas et al. 2003).

The detection limits of the technique demonstrated the sensitivity of PCR for $C$. fetus, and similar data has been reported for Campylobacter mucosalis (Bastyns et al. 1994). The same detection limits were observed for both dilutions inoculated with ultrapure water and TEM added to preputial and/or cervical mucus and abomasum contents suggesting that the possible inhibitors of the PCR reaction present in the inoculated transport medium had no affect on the final result of the technique. In the current study, this inhibition was not observed, most likely because of the CTAB protocol, which can remove most of the possible inhibiting substances (Hernandez et al. 1995, Honoré-Bouakline et al. 2003).

From the total clinical samples examined, $12.5 \%$ of the animals and $40.8 \%$ of the farms examined were PCR positive for $C$. fetus. The PCR results from the prepuce samples and cervical aspirate demonstrated that females are more likely to be susceptible to $C$. fetus detection than males. However, the number of samples used to compare the differences between males and females were relatively small; therefore, a larger sample group is necessary to obtain a definitive conclusion about sexual differences.

The fact that more females than males were positive for $C$. fetus could be related to the amount of mucus collected (larger volume of mucus collected from females), mainly during the estrous cycle, which could be induced by the use of hormones. These findings conflict with most of the current BGC diagnostic recommendations, in which bulls are considered as the ideal source for sampling (Pellegrin 1999, McMillen et al. 2006). The low performance in the detection of $C$. fetus in bulls could be related to the low 
availability of material that could be collected, mainly in Bos indicus breeds and in young bulls, where the prepuce folds and its crypts are less developed (Eaglesome \& Garcia 1992).

The 5-days period of sample incubation prior to DNA extraction and PCR testing used in the current study was based on data obtained from a previous study (unpublished data) that indicated that the period of pre-enrichment in TEM provides a multiplication of the bacteria and an increase in PCR detection. However, during the current study, bacterial culture was performed on the third day, as recommended (Lander 1990, Oie 2004); because, after this period, the isolation of $C$. fetus is more difficult due to the increased growth of contaminating bacteria. The PCR diagnosis was obtained within 5 days, while the results of the final identification by culture took at least 10 days.

When PCR and isolation techniques were compared, a greater sensitivity was observed in the PCR relative to culture. In the statistical analysis, the kappa value of 0.2 depicts a very small agreement between the techniques; this occurred because the isolation showed reduced sensitivity to $C$. fetus. The PCR technique presented in the current study cannot discriminate between $C$. fetus subsp. fetus and $C$. fetus subsp. venerealis, however, the high sensitivity and low cost of this technique compared to culture may be very useful in epidemiological studies and as a screening tool for $C$. fetus. The relevance of subspecies discrimination is dubious due the significant prevalence of C. fetus subsp. venerealis in reproductive tract samples. In a second PCR, $C$. fetus subsp. venerealis was detected in all tested samples confirming previous reports of the occurrence of these subspecies in Brazilian herds (Vargas et al., 2003) and indicating the technical potential to subspecies differentiation although more detailed studies are until necessary to prove this hypotheses. Therefore, a multiplex PCR to direct detection of microorganisms may produce mistakes due to DNA quality and PCR reagents standardization (McPherson \& Moller 2000).

Although the objective of the present study was not to determine the prevalence of BGC, since samples were only obtained from farms with a history of infertility, the results demonstrated more farms positive by PCR $(61.3 \%$; $19 / 31)$ relative to culture isolation $(6.4 \%$; $02 / 31)$. Therefore, the use of the isolation technique as the only method of diagnosis would not identify $54.8 \%$ of the positive farms, compromising the epidemiological data and the control programs. In summary, the PCR technique was more sensitive and specific for the detection of $C$. fetus when compared with traditional isolation methods. The PCR is also faster and can be used as an effective alternative for genital campylobacteriosis diagnosis in cattle.

Acknowledgements.- Part of this research has been funded by "Conselho Nacional de Pesquisa e Desenvolvimento Tecnológico" (CNPq/ Brazil grant 521049/01-6), and "Fundação de Apoio a Pesquisa do Estado do Rio Grande do Sul" (FAPERGS/Brazil grants 01/0509.4, 01/ 600801 and 01/600813).

\section{REFERENCES}

Bastyns K., Chapelle S., Vandamme P., Goossens H. \& De Wachter R. 1994. Species-specific detection of Campylobacters important in veterinary medicine by PCR amplification of 23rDNA areas. Syst. Appl. Microbiol. 17:563-568.

Blom K., Patton C.M., Nicholson M.A. \& Swaminathan B. 1995. Identification of Campylobacter fetus by PCR-DNA probe method. J. Clin. Microbiol. 33:1360-1362.

Brooks B.W., Devenish J., Lutze-Wallace C.L., Milnes D., Robertson R.H. \& Berlie-Surujballi G. 2004. Evaluation of a monoclonal antibodybased enzyme-linked immunosorbent assay for detection of Campylobacter fetus in bovine preputial washing and vaginal mucus samples. Vet. Microbiol. 103:77-84.

Casadémont I., Bizet C., Chevrier D. \& Guesdon J. L. 2000. Rapid detection of Campylobacter fetus by polymerase chain reaction combined with non-radioactive hybridization using an oligonucleotide covalently bound to microwells. Mol. Cell. Probes 14:233240.

Catena M., Callejas S., Soto P., Aba M., Erchevaría H., Monteavaro C. \& Mazzolli A. 2003. Efectos de la infección experimental con Campylobacter fetus venerealis sobre la preñez temprana en vaquillonas. (Effect of experimental infection with Campylobacter fetus venerealis in early pregnancy of cattle). Invest. Vet. 5:37-44. (In Spanish).

Eaglesome M.D. \& Garcia M.M. 1992. Microbial agents associated with bovine genital tract infections and semen. I. Brucella abortus, Leptospira, Campylobacter fetus and Tritrichomas fetus. Vet. Bull. 62:743-775.

Hernandez J., Alonso J.L., Fayos A., Amoros I. \& Owen R. J. 1995. Development of a PCR assay combined with a short enrichment culture for detection of $C$. jejuni in estuarine surface waters. FEMS. Microbiol. Lett. 127:201-206.

Honoré-Bouakline S., Vincensini J.P., Giacuzzo V., Lagrange P.H. \& Herrmann J.L. 2003. Rapid diagnosis of extrapulmonary tuberculosis by PCR: impact of sample preparation and DNA extraction. J. Clin. Microbiol. 41:2323-2329.

Hum S., Quinn C. \& Kennedy D. 1994. Diagnosis of bovine venereal campylobacteriosis by ELISA. Aust. Vet. J. 71:140-142.

Hum S., Quinn K., Brunner J. \& On S.L.W. 1997. Evaluation of a PCR assay for identification and differentiation of Campylobacter fetus subspecies. Aust. Vet. J. 75:827-831.

Lander K.P. 1990. The development of a transport and enrichment medium for Campylobacter fetus. Brit. Vet. J. 146:327-333.

McFadden A.M., Heuer C., Jackson R., West D.M. \& Parkinson T.J. 2005. Investigation of bovine venereal campylobacteriosis in beef cow herds in New Zealand. N. Z. Vet. J. 53:45-52.

McMillen L., Fordyce G., Doogan V.J., Lew A.E. 2006. Comparison of culture and a novel 5'Taq nuclease assay for direct detection of Campylobacter fetus subsp. venerealis in clinical specimens from cattle. J. Clin. Microbiol. 44:938-945.

McPherson M.J. \& Moller S.G. 2000. PCR. Springer Bios, New York, p.34-35.

Muller W., Hotzel H. \& Schulze F. 2003. Identification and differentiation of Campylobacter fetus subspecies by PCR. Dtsch. Tierärztl. Wochenschr. 110:55-59.

On S.L.W. \& Harrington C.S. 2001. Evaluation of numerical analysis of PFGE-DNA profiles for differentiating Campylobacter fetus subspecies by comparison with phenotypic, PCR and 16S rDNA sequencing methods. J. Appl. Microbiol. 90:285-293.

Oyarzabal O.A., Wesley I.V., Harmon K.M., Schoeder-Tucker L., Barbaree J.M., Backert S. \& Conner D.E. 1997. Specific identification of Campylobacter fetus by PCR targeting variable regions of the $16 \mathrm{~S}$ rDNA. Vet. Microbiol. 58:61-71. 
Pellegrin A.O. 1999. A campilobacteriose e tricomonose são doenças reemergentes. Revta Bras. Reprod. Anim. 23:523-531.

Pitcher D.G., Saunders N.A. \& Owen R.J. 1989. Rapid extraction of bacterial genomic DNA with guanidium thyocianate. Lett. Appl. Microbiol. 8:151-156.

Rapley R. \& Walker J.M. 1998. Molecular biomethods handbook. Humana Press, Totowa, NJ.

Sambrook R. \& Russel D.W. 2001. Molecular Cloning: A laboratory manual. Vol.1. $3^{\text {rd }}$ ed. Cold Spring Harbor Laboratory Press, New York, p.662.
Vargas A.C., Costa M.M., Vainstein M.H., Kreutz L.C. \& Neves J.P. 2003. Phenotipic and molecular characterization of bovine Campylobacter fetus strains isolated in Brazil. Vet. Microbiol. 93:121-132.

Wagenaar J.A., Bergen V.M., Newell D.G., Thomas R.G. \& Duim B. 2001. Comparative study using amplified fragment length polymorphism fingerprinting, PCR genotyping, and phenotyping to differentiate Campylobacter fetus strains isolated from animals. J. Clin. Microbiol. 39:2283-2286.

OIE 2004. OIE Manual of Diagnostic Tests and Vaccines for Terrestrial Animals. $5^{\text {th }}$ ed. World Animal Health Organization, Paris. 